\title{
PROFIL REPRESENTASI MATEMATIS SISWA BERGAYA VERBALIZER DALAM MENYELESAIKAN SOAL PISA
}

\author{
Winda Adelya Rosa \\ STKIP PGRI Sidoarjo \\ windadelyar@gmail.com \\ Intan Bigita Kusumawati \\ STKIP PGRI Sidoarjo \\ bigita.intan@gmail.com \\ Soffil Widadah \\ STKIP PGRI Sidoarjo \\ Soffdah16@gmail.com
}

\begin{abstract}
Abstrak
Dalam pembelajaran matematika setiap individu memiliki cara yang berbeda dengan individu lain dalam menyajikan kembali gagasan-gagasan matematis yang didapatkan dari proses pemikiran yang kemudian disampaikan dalam bentuk tulisan sebagai model atau bentuk pengganti yang mewakili bentuk lain dari permasalah yang ada untuk menemukan solusi dari masalah tersebut. Perbedaan cara penyajian kembali gagasangagasan matematis ini disebut kemampuan representasi matematis.Tujuan dari penelitian ini adalah untuk mendeskripsikan representasi matematis siswa bergaya kognitif verbalizer dalam menyelesaikan soal PISA. Jenis penelitian ini adalah penelitian deskriptif dengan menggunakan pendekatan kualitatif. Penelitian ini dilaksanakan pada tahun ajaran 2019/2020 di SMA Muhammadiyah 3 Tulangan kelas X MIPA 3. Penentuan subjek dilakukan dengan memberikan angket gaya kognitif visualizer-verbalizer. Diperoleh subjek penelitian yaitu satu siswa bergaya kognitif verbalizer. Analisis data dalam penelitian ini meliputi: mereduksi, menyajikan, dan menarik kesimpulan kemampuan representasi matematis siswa dalam menyelesaikan soal PISA. Dari penyelesaian soal tes yang diberikan serta wawancara yang dilakukan kepada subjek, diperoleh representasi matematis yang digunakan adalah representasi verbal.
\end{abstract}

Kata Kunci: gaya kognitif; representasi matematis; soal

PISA; verbalizer.

\begin{abstract}
In the process of learning mathematics, every individual owns its own way of presenting their mathematical ideas in which those ideas are accumulated from the thinking process that are presented in written form of the model of problem solving and solution. Different way of those mathematical ideas is defined as representation.The aim of this research is to describe the representation skills of student by using cognitive style;
\end{abstract}


verbalizer to answer PISA test. This research used descriptive research design for qualitative research method. This research was done at X MIPA 3 SMA Muhammadiyah 3 Tulangan with academic year 2019/2020. In deciding the subjects, this research employs a questionnaire with cognitive styles; visualizer and verbalizer. The result of the questionnaire showed that there are one student for verbalizer as a research subjects. In analyzing the data, there are three steps, namely data reduction, data display, and conclusion drawing for students' ability in finishing the PISA test. Based on the result of the test and the interview, verbal representation is the representation that used verbalizer cognitive style' students

Keywords: cognitive style; mathematical representation;

PISA problems; verbalizer

\section{PENDAHULUAN}

Pembelajaran matematika pada pendidikan formal perlu mendapat perhatian khusus dalam perkembangannya. Siswa perlu dibekali kemampuan matematis yang matang agar dapat mewujudkan tujuan pembelajaran matematika itu sendiri, seperti yang disebutkan pada Peraturan Kementrian Pendidikan dan Kebudayaan Nasional RI, yakni sebagai berikut:

Permendiknas No. 22 Tahun 2006 tanggal 23 Mei 2006, tentang Standar isi pada lampirannya menegaskan bahwa tujuan pembelajaran matematika adalah: memahami konsep matematika, menjelaskan keterkatian antar konsep dan mengaplikasikan konsep atau algoritma, secara luwes, akurat, efisien, dan tepat dalam pemecahan masalah; (2) menggunakan penalaran pada pola dan sifat, melakukan manipulasi matematika dalam membuat generalisasi, menyusun bukti, atau menjelaskan gagasan dan pernyataan matematika; (3) memecahkan masalah yang meliputi kemampuan memahami masalah, merancang model matematika, menyelesaikan model dan menafsirkan solusi yang diperoleh; mengkomunikasikan gagasan dengan simbol, tabel, diagram, atau media lain untuk memperjelas keadaan atau masalah; (5) memiliki sikap menghargai kegunaan matematika dalam kehidupan, yaitu memiliki rasa ingin tahu, perhatian, dan minat dalam mempelajari matematika, serta sikap ulet dan percaya diri dalam pemecahan masalah.

Berdasarkan tujuan pembelajaran matematika tersebut dapat diperoleh bahwa salah satu kemampuan yang harus dimiliki siswa saat pembelajaran matematika adalah kemampuan dalam 
menampilkan bahasa matematika berupa simbol, tabel, dan diagram yang kesemuanya itu bertujuan untuk memodelkan masalah matematika.

Dalam hal ini kemampuan representasi matematis adalah salah satu kemampuan yang ingin dicapai.

Representasi adalah salah satu kemampuan matematika yang harus dimiliki oleh siswa di era globalisasi ini. Hal tersebut dikarenakan penggunaan representasi dalam mengolah informasi, komunikasi dan pembelajaran berkembang dengan pesat (Verschaffel, 2010). Representasi matematis adalah menyajikan kembali gagasan-gagasan matematis yang didapatkan dari proses pemikiran yang kemudian disampaikan bentuk tulisan sebagai model atau bentuk pengganti yang mewakili bentuk lain dari permasalahan yang ada untuk dihadapi dan menemukan solusi dari masalah tersebut.Mudzakir (2006) menguraikan representasi matematika ke dalam bentuk- bentuk operasional berikut.

Tabel 1.Bentuk-bentuk Operasional Matematika Menurut Mudzakir (2006)

\begin{tabular}{|c|c|c|}
\hline No & Representasi & Bentuk - Bentuk Operasional \\
\hline 1 & $\begin{array}{l}\quad \text { Visual : } \\
\text { a. Diagram, grafik atau } \\
\text { tabel } \\
\text { b. Gambar }\end{array}$ & $\begin{array}{l}\text { a. Menyajikan kembali data atau informasi dari suatu } \\
\text { representasi ke representasi diagram, grafik atau tabel. } \\
\text { b. Menggunakan representasi visual untuk menyelesaikan } \\
\text { masalah. } \\
\text { c. Membuat gambar atau bangun geometri untuk memperjelas } \\
\text { masalah dan memfasilitasi penyelesaiannya. }\end{array}$ \\
\hline 2 & $\begin{array}{l}\text { Simbolik: } \\
\text { Persamaan atau } \\
\text { ekspresi matematik }\end{array}$ & $\begin{array}{l}\text { a. Membuat persamaan atau model matematis dari } \\
\text { representasi lain yang diberikan. } \\
\text { b. Penyelesaian masalah dengan melibatkan ekspresi } \\
\text { matematis }\end{array}$ \\
\hline 3 & $\begin{array}{l}\text { Verbal : } \\
\text { Kata-kata atau teks } \\
\text { tertulis }\end{array}$ & $\begin{array}{l}\text { a. Membuat situasi masalah berdasarkan data atau } \\
\text { representasi yang diberikan } \\
\text { b. Menulis interprestasi ke dalam suatu kata-kata atau } \\
\text { kalimat. } \\
\text { c. Menuliskan langkah-langkah penyelesaiaan masalah } \\
\text { matematis dengan kata-kata tanpa penyimbolan } \\
\text { matematika. } \\
\text { d. Menyusun cerita yang sesuai dengan suatu representasi } \\
\text { yang disajikan. } \\
\text { e. Menyelesaikan soal dengan menggunakan kata-kata atau } \\
\text { teks tertulis }\end{array}$ \\
\hline
\end{tabular}


Agus Triono (2017) menyatakan bahwa sebagian siswa sudah mampu menggunakan representasi verbal meskipun beberapa dianataranya masih belum bisa menyampaikan ide matematisnya dengan bahasa sendiri. Kemampuan representasi verbal masing kurang terasah dikarenakan siswa lebih banyak menggunakan bentuk representasi simbolik ketika menyelesaikan suatu masalah. Penelitian yang dilakukan oleh Riszki (2019) diperoleh bahwa dalam pembelajaran siswa selalu dipahamkan dengan proses simbol, sehingga siswa akan merasa kebingungan jika dihadapkan dengan suatau masalah yang penyampaiannya harus berupa kata-kata atau dalam bentuk verbal.

Representasi yang digunakan setiap individu dalam menyelesaikan masalah tentu berbeda-beda. Perbedaan tersebut menyebabkan siswa memiliki cara dan karakteristik yang berbeda dalam menerima, mengolah, dan memahami informasi. Perbedaan-perbedaan yang dimiliki siswa ini dikenal dengan gaya kognitif.

Beberapa peneliti telah mengusulkan berbagai dimensi dalam gaya kognitif. Paivio (dalam Kozhevnikov 2007:468) mengusulkan bahwa gaya kognitif dibagi menjadi dua dimensi yaitu visualizer dan verbalizer. Siswa yang cenderung bergaya kognitif visualizerakan menggunakan gambar untuk memproses suatu informasi. Siswa yang cenderung bergaya kognitif verbalizerakan menggunakan kata-kata atau kalimat dalam memproses suatu informasi.

McEwan \& Reynolds (2007) mengemukakan pendapat mengenai gaya kognitif yang berkaitan dengan kebiasaan dalam menggunakan alat indera dibagi menjadi dua kelompok, yaitu visualizer dan verbalizer. Perbedaan dua gaya kognitif ini disebabkan oleh kemampuan seseorang dalam mengimajinasikan suatu informasi yang telah diperoleh. Siswa yang termasuk dalam kelompok visualizer cenderung menggunakan indera pengihatannya untuk memperoleh informasi dan mengolahnya dalam bentuk gambar. Sedangkan kelompok siswa verbalizer cenderung menggunakan indera pendengarannya untuk memperoleh informasi dan mengolahnya dalam bentuk teks.

Salah satu paya untuk melihat sejauh mana kemampuan representasi matematis siswa Indonesia adalah dengan terlibatnya Indonesia dalam 
Programme for International Student Assessment (PISA). PISA merupakan sebuah program penilaian siswa tingkat internasional yang diselenggarakan oleh Organisation forEconomic Cooperation and Development (OECD) atau organisasi untuk kerjasama ekonomi dan pembangunan. Sebagaimana studi yang dilakukan oleh Trends in International Mathematics and Science Study (TIMSS) danPISA di beberapa Negara termasuk salah satunya Indonesia, menyebutkan bahwa representasi termasuk salah satu aspek dalam penilaian literasi matematika. PISA mengukur kemampuan siswa pada usia 15 tahun 3 bulan sampai 16 tahun 2 bulan untuk mengetahui kesiapan siswa menghadapi tantangan masyarakat pengetahuan dewasa ini. Indonesia telah mengikuti studi PISA sejak tahun 2000 dan terakhir adalah pada tahun 2018.

Berdasarkan penjelasan yang telah disampaikan, peneliti tertarik untuk melakukan penelitian dengan judul "Profil Representasi Matematis Siswa Bergaya Kognitif Verbalizer Dalam Menyelesaikan Soal PISA".

\section{METODE}

Penelitian ini adalah penelitian kualitatif deskriptif yang bertujuan untuk mendeskripsikan representasi matematis siswa bergaya kognitif verbalizer dalam menyelesaikan soal PISA.Penelitian ini dilaksanakan di SMA Muhammadiyah 3 Tulangan pada tahun ajaran 2019/2020 semester genap.Pengambilan subjek penelitian dengan melihat hasil angket Visualizer and Verbalizer Questioner (VVQ).Kemudian dipilih satu subjek bergaya verbalizer dengan skor tertinggi.

Instrumen pada penelitian ini terdiri dari instrumen utama yaitu peneliti sendiri dan instrumen pendukung yang meliputi angket VVQ, soal tes dan pedoman wawancara. Angket, soal tes dan wawancara yang akan digunakan divalidasi terlebih dahulu oleh validator. Data yang dikumpulkan pada penelitian ini adalah data kemampuan representasi matematis siswa begaya kognitif visualizer-verbalizer yang dilihat dari pemberian angket, teknik tes dan wawancara.

Keabsahan data yang digunakan adalah triangulasi teknik. Triangulasi teknik dilakukan untuk mengecek informasi atau data antara hasil juga meminta pendapat 
guru matematika yang wawancara dan tes. Pemilihan triangulasi ini didasarkan pada tujuan penelitian yaitu untuk membandingkan data yang diperoleh dengan teknik yang berbeda yaitu, teknik pemberian soal dan wawancara. Teknik untuk menganalisis data adalah dengan cara reduksi, penyajian data dan penarikan kesimpulan

\section{HASIL DAN PEMBAHASAN}

Pengisian angket VVQ digunakan untuk menentukan subjek penelitian.Hasil angket VVQ yang diberikan kepada 29 siswa menunjukkan bahwa terdapat 1 siswa yang bergaya kognitif verbalizer dengan skor paling tinggi. Selain skor angket, usia siswa juga diperhatikan dalam memilih subjek. Peneliti juga meminta pendapat guru matematika yangbersangkutan dalam memilih siswa yang akan dijadikan subjek penelitian. Adapun siswa yang diambil sebagai subjek penelitian adalah subjek HAW yang berusia 16 tahun 2 bulan pada saat penelitian berlangsung.

$$
\text { Setelah diperoleh subjek }
$$
penelitian, langkah selanjutnya adalah memberikan soal tes dan melakukan wawancara untuk mengetahui representasi matematis subjek HAW.Berikut ini adalah hasil jawaban tertulis subjek HAW dalam menyelesaikan soal tes.

$$
\text { Jawaban tertulis subjek HAW }
$$
menunjukkan bahwa subjek menuliskan langkah-langkah penyelesaian soal dengan menuliskan pemodelan dari apa yang diketahui soal dan menyusun kalimat atau bercerita untuk menarik kesimpulan dan memperoleh jawaban yang sesuai. Langkah-langkah penyelesaian yang dituliskan subjek Ve2 memunculkan dua jenis representasi yaitu representasi simbol dan representasi verbal.Penggunaan representasi simbol ditunjukkan pada ekspresi matematika yang ditulis subjek dalam bentuk pemodelan terkait bahan-bahan yang dibutuhkan. Selain itu, jawaban dari subjek HAW memenuhi indikator dari representasi verbal yaitu "Menyusun cerita yang sesuai dengan suatu representasi yang disajikan." dan "Membuat situasi masalah berdasarkan data atau representasi yang diberikan". Sehingga dapat disimpulkan bahwa subjek HAW menggunakan representasi verbal untuk menyelesaikan soal PISA tersebut.

Tahap selanjutnya setelah menganalisis jawaban tes adalah 


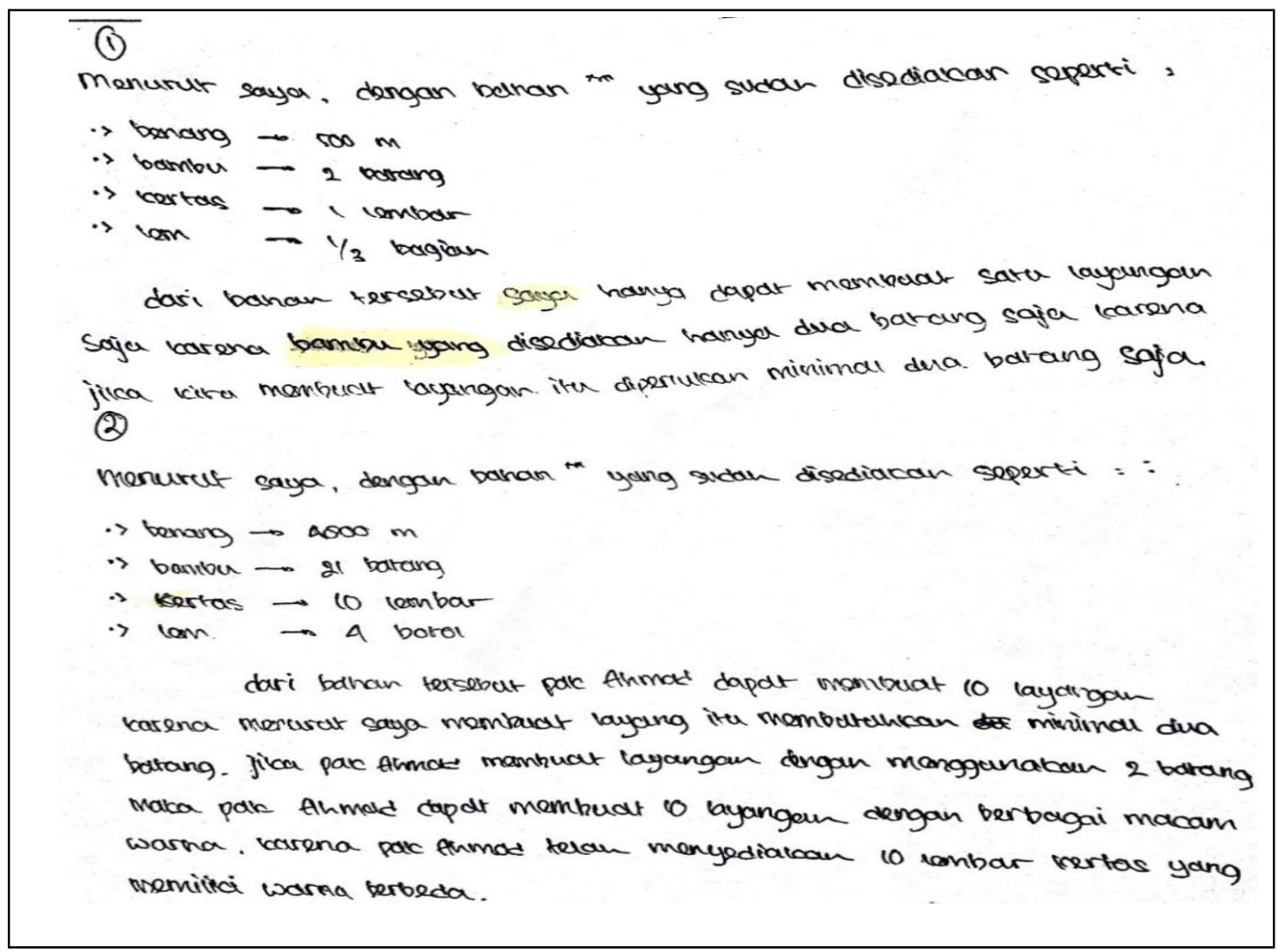

Gambar 1.Jawaban tertulis subjek HAW

melakukan wawancara untuk meceritakan secara detail dari yang mencocokkan jawaban Ve1 dalam diketahui hingga memperoleh hasil menyelesaikan soal PISA. Hasil akhirnya. Sehingga dapat disimpulkan wawancara dengan subjek HAW diketaui bahwa subjek HAW menggunakan bahwa subjek mengatakan jika langkah representasi verbal dalam menyelesaikan yang digunakan untuk menyelesaikan soal soal PISA tersebut dengan indikator PISA tersebut adalah dengan merangkai representasi verbal yang sesuai yaitu kata-kata.Subjek HAW juga mengatakan bahwa dia tidak suka perhitungan dan permisalan serta tidak suka menggambar untuk menyelesaikan soal tersebut dikarenakan lebih rumit dan lebih sulit. Dari penjelasan subjek HAW juga "Menyusun cerita yang sesuai dengan suatu representasi yang disajikan." dan indikator "Menyelesaikan soal dengan menggunakan kata-kata atau teks tertulis." menunjukkan bahwa subjek lebih suka terhadap subjek HAW dapat diketahui 
bahwa siswa dengan gaya kognitif verbalizer menggunakan representasi verbal dalam menyelesaikan soal matematika. Hasil tersebut sejalan dengan penelitian yang dilakukan Ilma (2017) bahwa seseorang dengan gaya kognitif verbalizer memiliki kecenderungan dalam memperoleh informasi dengan cara mendengar sehingga lebih mudah menerima, memproses, menyimpan maupun menggunakan informasi dalam bentuk teks atau tulisan. Pendapat McEwan \& Reynolds (2007) juga mendukung hasil dari penlitian ini, yang menyatakan bahwa kelompok siswa verbalizer cenderung menggunakan indera pendengarannya untuk memperoleh informasi dan mengolahnya dalam bentuk teks.

\section{SIMPULAN}

Berdasarkan hasil penelitian yang dilakukan dan telah dibahas dapat disimpulkan bahwa dalam menyelesaikan soal PISA yang digunakan sebagai soal tes, siswa bergaya bergaya kognitif verbalizer menggunakan representasi verbal dalam menyelesaikan soal PISA yang digunakan sebagai soal, meskipun dikombinasikan dengan representasi simbol untuk membuat permodelan dari soal sebagai langkah awal. Namun, siswa verbalizer cenderung menggunakan representasi verbal saat proses penyelesaian soal hingga menyimpulkan jawaban.

\section{DAFTAR PUSTAKA}

Ilma, R., Hamdani, A.S., Lailiyah, S. (2017). Profil berpikir analitis masalah aljabar siswa ditinjau dari gaya kognitif visualizer dan verbalizer. Jurnal Review Pembelajaran Matematika, 2(1), 1-14.doi :https://doi.org/10.15642/jrpm.2017.2. $\underline{1.1-14}$

Mudzakkir, H. S. (2006). Strategi Pembelajaran Think-Talk-Write untuk Meningkatkan Kemampuan Representasi Matematik Beragam Siswa SMP. Disertasi Tidak dipublikasikan. UPI Bandung.

OECD. (2013). PISA 2012 Assessment and Analytical Framework: Mathematics, Reading, Science, Problem Solving and Financial Literacy. Paris: OECD Publishing. Diambil

https://www.oecd.org/pisa/pisaproduct s/PISA\%202012\%20framework\%20ebook_final.pdf

Permendiknas, R. I. (2006). No 22 Tahun2006. Tentang Standar Isi untuk Satiuan Pendidikan Dasar dan Menengah”. Jakarta: Depdiknas. 
Riszki, D. N. (2019). Analisis Kemampuan Representasi Matematis Siswa Dalam Menyelesaikan Soal Matematika Materi Sistem Persamaan Linier Tiga Variabel Kelas X SMA Negeri 1 Tulungagung. Tulungagung. Diambil dari http://repo.iaintulungagung.ac.id/id/eprint/12976

Rosita, Y. S. (2016). Profil Kemampuan Representasi Matematika Siswa Dalam Menyelesaikan Soal Matematika Ditinjau Dari Gaya Kognitif Visualizer Verbalizer.Skripsi Tidak Dipublikasikan. Sidoarjo, STKIP PGRI SIDOARJO.

Triono, A. (2017). Analisis Kemampuan Representasi Matematis Siswa Kelas VIII Smp Negeri 3 Tangerang Selatan (Bachelor's thesis).Tesis Tidak dipublikasikan . Jakarta, UIN Syarif Hidayatullah. 
Rosa, Profil Representasi ... 